\title{
APLIKASI PENGUKUR 3 DERAJAT KEBEBASAN GAYA AERODINAMIKA PADA WATER TUNNEL
}

\author{
Rendra Dwi Firmansyah ${ }^{1}$,Setiawan Bekti Wibowo ${ }^{2}{ }^{,}$Rella Mareta ${ }^{3}$
}

\section{1,3 Departemen Teknik Elektro dan Informatika,Sekolah Vokasi, Universitas Gadjah Mada Yogyakarta,Indonesia \\ ${ }^{2}$ Departemen Teknik Mesin, Sekolah Vokasi,Universitas Gadjah Mada Yogyakarta,Indonesia}

\author{
firmansyah_1412@ugm.ac.id ${ }^{1}$, setyawanbw@ugm.ac.id²,rella.mareta@ugm.ac.id ${ }^{3}$
}

\begin{abstract}
Abstrak
Perkembangan teknlogi pesawat tanpa awak berkembang pesat.Dalam pembuatan sebuah peswat diperlukan analisis mengenai gaya-gaya aerodinamika yang bekerja pada pesawat tersebut. Analisis gaya aerodinamika dapat dilakukan melaui wind tunnel dan water tunnel. Pengukuran dapat dilakukan dengan visualisasi tetapi metode ini tidak memberikan nilai gaya aerodinamika secara langsung. Sehingga analisis gaya aerodinamika tidak dapat dilakukan secara langsung. Pengukuran gaya aerodinamika dapat dilakukan menggunakan sistem pengukur gaya dengan sensor load cell. Aplikasi sistem pengukur gaya aerodinamika dapat membuat analisis gaya aerodinamika secara langsung karena nilai pembacaan gaya langsung ditampilkan dalam bentuk grafik. Alat ukur ini menggunakan Load cellsebagai sensor, data dari load cell lalu di olah menggunakan mikrokontroler dan ditampilkan di komputer. Setelah dilakukan pengujian, alat pengukur gaya ini dapat mengukur gaya Drag dan gaya Lift sesuai dengan beban yang diujikan dengan error kecil. Selain itu, gaya momen dapat diketahui menggunakan sistem pengukur gaya ini. Sehingga sistem ini dapat mengukur gaya aerodinamika dengan 3 derajat kebebasan Sistem pengukur gaya ini juga bisa menunjukkan arah gaya aerodinamika yang dialami oleh obyek tes.
\end{abstract}

Katakunci:Peswawat tanpa awak, Load Cell, Mikrokontroler, Gaya Aerodinamika

\begin{abstract}
The development of unmanned aircraft technology developed rapidly. In making an airplane, an analysis of the aerodynamic forces acting on the aircraft is required. Analysis of aerodynamic forces can be done through wind tunnels and water tunnels. Measurements can be performed by visualization but this method does not provide a direct aerodynamic force value. This aerodynamic force analysis cannot be done directly. Measurements of aerodynamic forces can be performed using a force measuring system with load cell sensors. The application of the aerodynamic force measuring system can make an aerodynamic force analysis directly because the force reading values are displayed directly in graphical form. This measuring instrument using Load cell as a sensor, data from the load cell are processed using a microcontroller and displayed on the computer. After testing, this measuring system can measure the Drag force and Lift force according to the load tested with small error. In addition, the momentum force can be known using this measuring system. So this system can measure aerodynamic force with 3 degrees of freedom. This force measuring system can also indicate the direction of aerodynamic forces experienced by the test object.
\end{abstract}

Keywords: Unmanned Aerial Vehicle, Load Cell, Microcontroller, Aerodynamics Force

\section{PENDAHULUAN}

Teknologi pesawat terbang tanpa awak atau yang sering disebut UAV (Unmanned Aerial Vehicle) berkembang dengan sangat pesat di Indonesia. Penelitian tentang pesawat tanpa awak banyak dilakukan mulai dari pembuatan, pengendalian sampai penggunaan. 
Pembuatan pesawat tanpa awak tidak dapat dilakukan sembarangan, diperlukan analisis mengenai gaya-gaya aerodinamika yang bekerja pada pesawat(Husnayati \& Moelyadi, 2013)

Analisis gaya aerodinamika dapat dilakukan dengan dua cara yaitu analisi simulasi (Lubis, 2012) dan melalui pengukuran menggunakan sensor gaya( $\mathrm{Ma}$ \& Song, 2013). Analisis gaya aerodinamika dapat disumulasikan menggunakan Computional Fluid Dinamic (CFD). Selain menggunakan simulasi, analisis Gaya aeorodinamika dapat dilakukan dengan pengukuran langsung menggunakan test section yang dipasang pada wind tunnel(Good, Howell, Passmore, \& Cogotti, 1998)atau water tunnel(Erm, 2004).

Gaya yang diukur dalam windtunnel dan waterunnel antara lain Lift, Drag, dan Roll. Lift adalah gaya angkat dari sebuah airfoil. Drag adalah gaya dari airfoil untuk menahan laju fluida (Nan, 2013). Roll adalah momen gaya antara drag dan lift.

Penelitian tentang pengukuran gaya aerodinamika telah dilakukan oleh beberapa peneliti baik dalam windtunnel maupun watertunnel. (Thrift, Brumbaugh, \& Thole, 2010) mengusulkan metode pengukuran gaya lift dan drag dalam sebuah silinder dengan satu array dengan aspek rasio 1 . Dengan metode ini, hasil pengukuran dapat langsung dibandingkan dengan nilai prediksi drag dan lift yang dihasilkan oleh simulasi.(Erm, 2004) melakukan tes dinamik untuk pesawat model dalam water tunnel. Metode yang digunakan dalam penelitian ini adalah menggunakan 5 komponen strain gauge untuk mengukur gaya dan momen. Metode ini juga dilengkapi dengan fitur penangkap gambar untuk melihat visualisasi gaya yang terjadi pada airfoil.

Pengukuran dengan menggunakan visualisasi gaya juga dilakukan oleh(Beckner \& E.Curry, 1985). Cristine Beckner and robert $\mathrm{E}$ curry menggunakan laser untuk mendapatkan visualisasi dari gaya aerodinamika.

Pengukuran profil drag sayap juga dilakukan oleh(Pifer \& Bramesfeld, 2012). Metode yang digunakan dalam penelitian ini adalah mengintegerasikan konsep wake rake. Metode ini sangat cocok untuk pengukuran pesawat tipe glider. Perbedaan metode ini dengan metode konvensional terletak pada proses pengolahan data setelah pengukuran. Dalam pendekatan iterasi, gaya yang terukur akan dikoreksi untuk mengkompensasi adanya pola yang tidak diketahui dan parameter yang tidak diketahui. Metode telah berhasil diterapkan untuk mengukur profil drag sayap selama penerbangan.

Pengukuran gaya aerodinamika menggunakan metode simulasi dapat memberikan informasi bentuk gaya yang terbentuk dari airfoil. Dengan metode ini dapat dilihat juga kapan gaya aerodinamika mengalami break down (aliran gaya pecah) yang menandakan sudut serang sudah maksimal. Namun pengukuran menggunakan visualisasi tidak dapat memberikan informasi berapa besar gaya yang dihasilkan oleh airfoil dan gaya maksimal yang dihasilkan pada saat breakdown. Informasi nilai gayasangat penting. Untuk mengatasi hal tersebut pengukuran langsung sangat disarankan. Pengukuran langsung dapat dilakukan dengan menggunakan sensor gaya baik strain gauge atau load cell.

Oleh karena itu diusulkan sebuah purwarupa sistem pengukur gaya aerodinamika yang dapat digunakan di dalam water tunnel. Purwarupa ini dapat mengukur tiga gaya aerodinamika yaitu lift, drag dan momen.

\section{METODE}

Beberapa metode pengukuran gaya aerodinamika telah diusulkan oleh beberapa peneliti diantaranya Purwarupa alat ukur terdiri dari 2 bagian yaitu perangkat keras dan perangkat lunak. Perangkat keras dibagi menjadi dua yaitu mekanik dan elektronik. Mekanik untuk alat ukur ini dirancang mengacu kepada beberapa desain penelitian yang dilakukan oleh (Yuan, Luo, Shin, \& Han, 2013)dengan beberapa modifikasi.

Komponen elektronik terdiri dari sensor load cell(Johnston, 1954; Muller, Brito, Pereira, \& Brusamarello, 2010)untuk mengukur gaya, penguat, dan mikrokontroler board sebagai prosesor. Perangkat lunak dibuat menggunakan 
labview untuk menampilkan nilai gaya aerodinamika yang terbaca oleh sensor dan sekaligus dapat menyimpan hasil pembacaannya di komputer. Diagram blok sistem ditunjukkan pada gambar 1

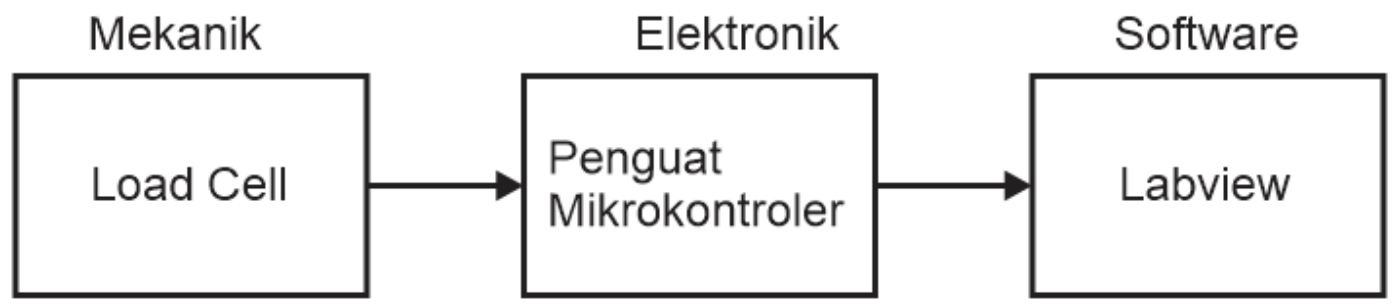

Gambar 1 Diagram Blok Sistem

Diagram blok yang ditunjukkan oleh gambar 1 menjelaskan bahwa sensor load cell dipasang di perangkat mekanik. Alat ukur gaya aerodinamika menggunakan 4 sensor load cell. Sensor loadcell membaca besar gaya yang terjadi dan mengubah menjadi tegangan yang nantinya dibaca oleh mikrokontroler. Load cell merupakan sensor yang terdiri empat strain gauge yang dirangkai dengan prinsip jembatan wheatstone (Doebelin, 2010).

Tegangan keluaran dari sensor tidak dapat langsung dibaca oleh mikrokontroler karena terlalu kecil sehingga membutuhkan penguatan. Penguatan tegangan load cellmenggunakan IC HX711. HX711 merupakan IC analog to digital converter (ADC) dengan resolusi 24 bit yang dirancang khusus untuk aplikasi yang menggunakan sensor dengan konfigurasi jembatan wheatstone. HX711 dapat diakses menggunakan mikrokontroler dengan komunikasi two wires interface (TWI).

Two wires interface merupakan salah satu jenis komunikasi yang dapat dilakukan oleh mikrokontroler dengan menggunakan dua pin mikrokontroler. 1 pin digunakan sebagai jalur data dan 1 pin lainnya digunakan sebagai jalur clock. Setalah mengakses data dari $\mathrm{HX} 711$, mikrokontroler akan mengolah data mentah dari HX711 yang kemudian dikonversi menjadi data gaya.

Data yang telah dikonversi, lalu dikirimkan ke computer melalui komunikasi serial. Data yang masuk ke computer kemudian akan ditampilkan oleh Labview sebagai Human Machine Interface (HMI). Labview akan menampilkan data dalam bentuk grafik. Data yang telah ditampilkan di HMI dapat disimpan di computer.

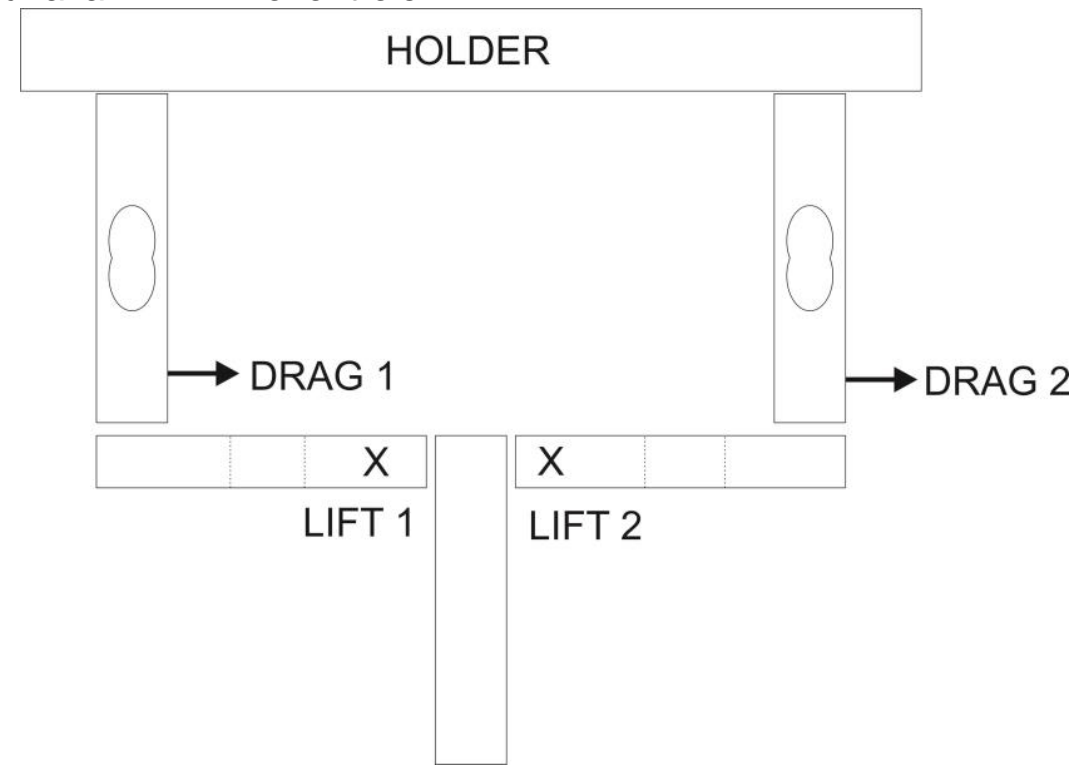

Gambar 2 Rancangan Mekanik tampak atas 
Gambar 2 menunjukkan rancangan mekanik tampak dari atas, serta arah gaya aerodinamika yang dapat diukur oleh aplikasi ini. Rancangan tersebut menggunakan empat/oad cell yang disusun sebagai berikut :

1. Menghadap ke atas untuk mengukur arah gaya keatas dan kebawah yang disebut dengan LIFT 1

2.Menghadap ke bawah untuk mengukur arah gaya keatas dan kebawah yang disebut dengan LIFT 2

3.2 load cell menghadap kesamping untuk mengukur arah gaya kesamping yang disebut dengan DRAG 1 dan DRAG 2

Arah gaya ditunjukkan oleh arah panah dan tanda $X$. Arah gaya drag kesamping kanan seperti yang ditunjukan oleh arah panah. Susunan drag dibuat searah karena gaya drag adalah gaya yang melawan aliran maka semua dihadapkan ke sumber aliran. Tanda $X$ menunjukkan bahwa arah gaya Lift adalah ke atas dan kebawah.

Implementasi dari rancangan tersebut ditunjukkan oleh gambar 3. Dalam Implementasinya masing-masing load cell tidak saling bersinggungan karena akan jika bersinggungan gaya yang terbaca akan rancu. Load cell yang dipakai pada test section adalah load cell $1 \mathrm{~kg}$. Test section ini juga dilengkapi dengan pengatur sudut serang. Serta pemegang model sayap atau model pesawat yang akan diuji.

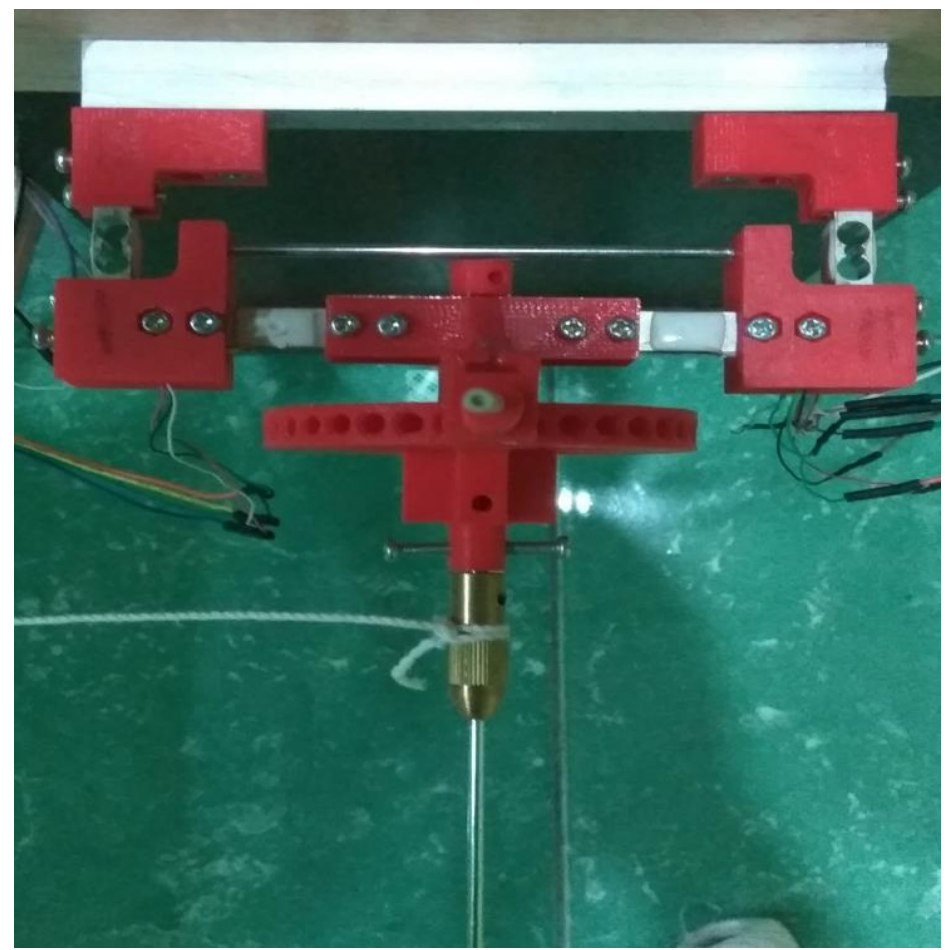

Gambar 3 Implementasi Mekanik

Gambar 4 menunjukkan aplikasi perangkat lunak untuk pengukur gaya aerodinamika untuk watertunnel. Aplikasi tersebut terdiri dari beberapa bagian. Bagian yang pertama adalah grafik. Grafik menampilkan hasil pembacaan data gaya aerodinamika yang telah dibaca oleh mikrokontroler. Gaya lift dan drag ditampilkan dalam satu grafik. Ada 4 warna grafik yang tampil pada bagian ini, putih untuk LIFT 1, merah untuk LIFT 2, biru untuk DRAG 1 dan hijau untuk DRAG 2. Aplikasi ini tidak hanya menampilkan data gaya aerodinamika dalam bentuk grafik, tetapi juga menampilkan data yang sedang dibaca oleh mikrokontroler secara real time.

Aplikasi ini juga dilengkapi dengan fitur penyimpanan data, jadi setalah melakukan pengukuran gaya aerodinamika data dapat disimpan di komputer. 
Penyimpanan dalam bentuk excel di direktori yang telah dituliskan di path file.

Komunikasi aplikasi dengan mikrokontroler melalui port serial. Jadi sebelum menjalankan aplikasi, harus dipilih nomor port yang digunakan. Tombol stop digunakan untuk menghentikan aplikasi.

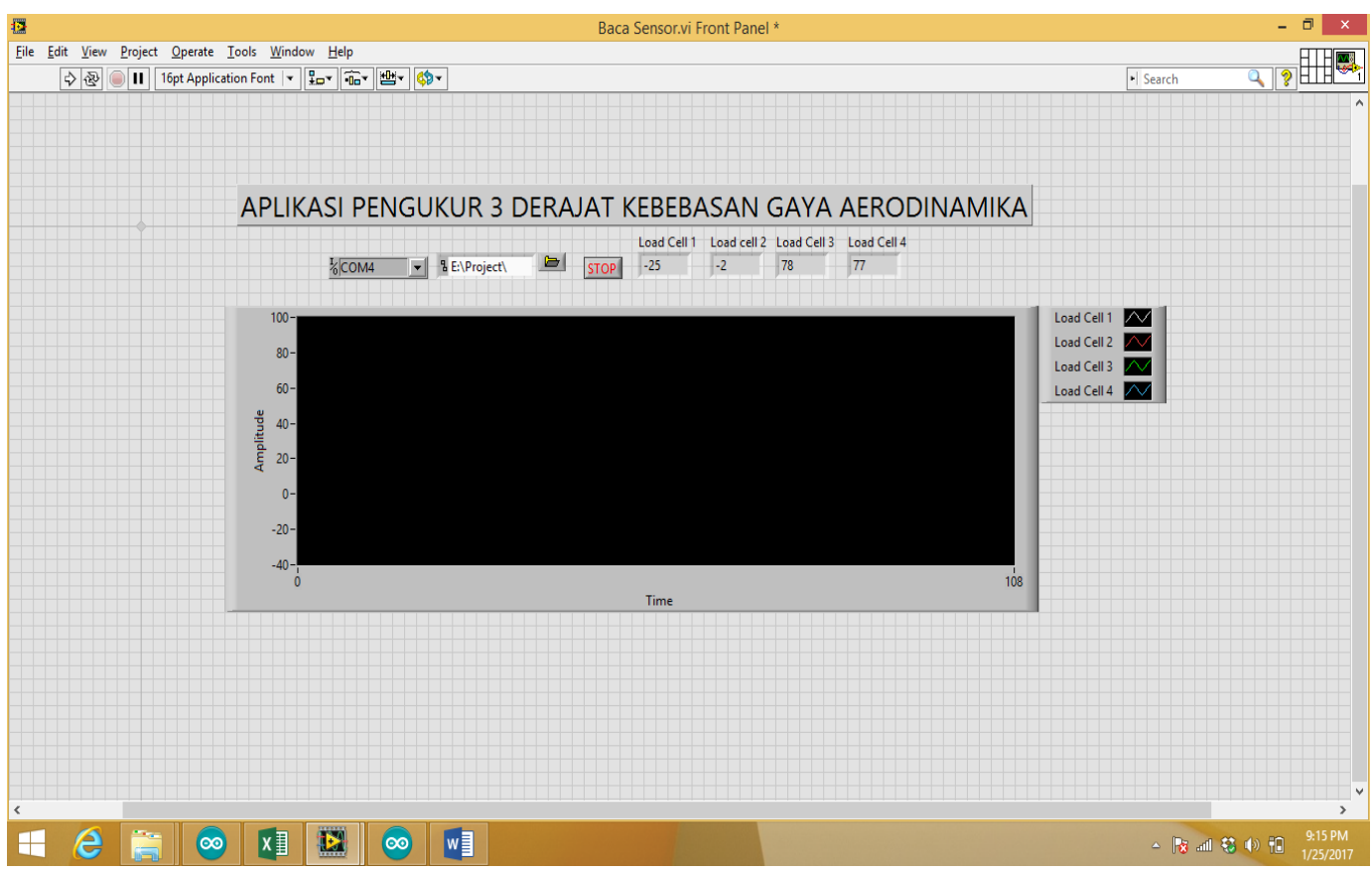

Gambar 4 Implementasi perangkat Lunak

\section{HASIL DAN PEMBAHASAN}

Percobaan dilakukan dengan beberapa tahap yaitu kalibrasi, pengukuran LIFT dan pengukuran DRAG. Kalibrasi dilakukan untuk memastikan nilai gaya yang terbaca load cell sama dengan gaya yang dibebankan pada load cell. Kalibrasi dilakukan pada masing-masing load cell dengan cara memberikan beban yang sudah diketahui beratnya kemudian diatur faktor kalibrasi di mikrokontroler.

Kalibrasi LIFT dilakukan dengan cara memberikan beban pada ujung alat ukur yang berwarna keemasan yang ditunjukkan oleh gambar 3. Beban yang digunakan untuk kalibrasi adalah $25 \mathrm{~g}$. Kalibrasi DRAG berbeda dengan pengukuran LIFT karena arah gaya nya kesamping bukan atasbawah sehingga diperlukan mekanisme pengukuran khusus untuk mendapatkan nilai DRAG. Cara pengukuran DRAG dilakukan dengan mengaitkan benang ke ujung alat ukur dan benang tersebut ditarik $45^{\circ}$ sehingga gaya yang dialami oleh load cellsama dengan gaya yang diberikan oleh benda yang diukur. Cara pengukuran ini ditunjukkan oleh gambar 5 . 


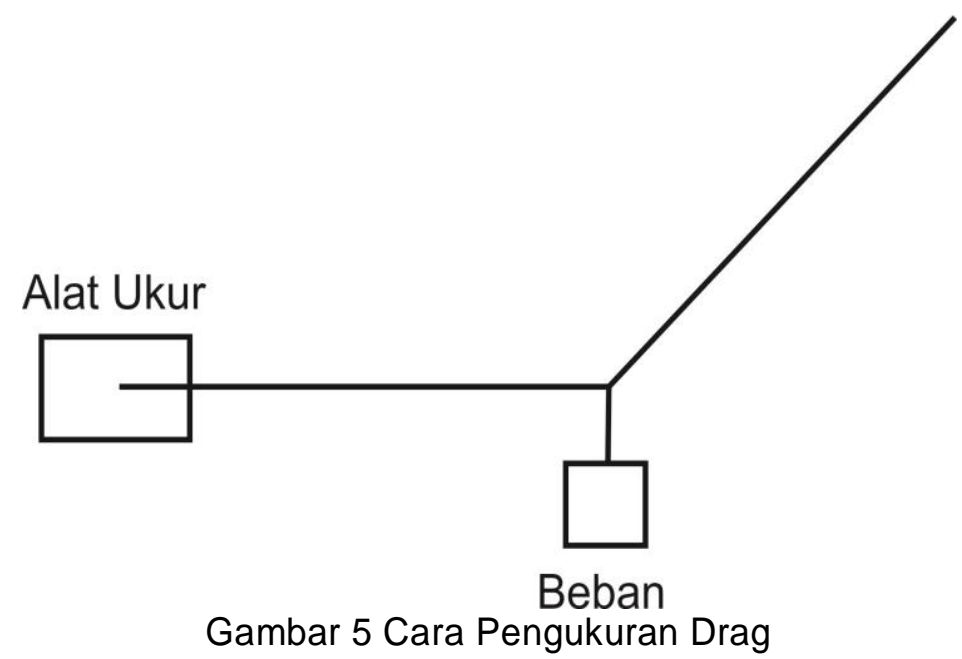

Pengukuran LIFT dan DRAG menggunakan 4 beban dengan berat yang berbeda. Keempat benda tersebut memiliki berat masing-masing sebesar $22 \mathrm{~g}, 25 \mathrm{~g}, 34 \mathrm{~g}$

dan $88 \mathrm{~g}$. Masing-masing benda diambil data sebanyak 100 kali.

Pengukuran LIFT dilakukan sebanyak empat kali dengan beban $22 \mathrm{~g}, 25 \mathrm{~g}, 34 \mathrm{~g}$ dan 88g. Hasil pengukuran LIFT dengan beban $22 \mathrm{~g}$ ditunjukkan oleh gambar 6 .

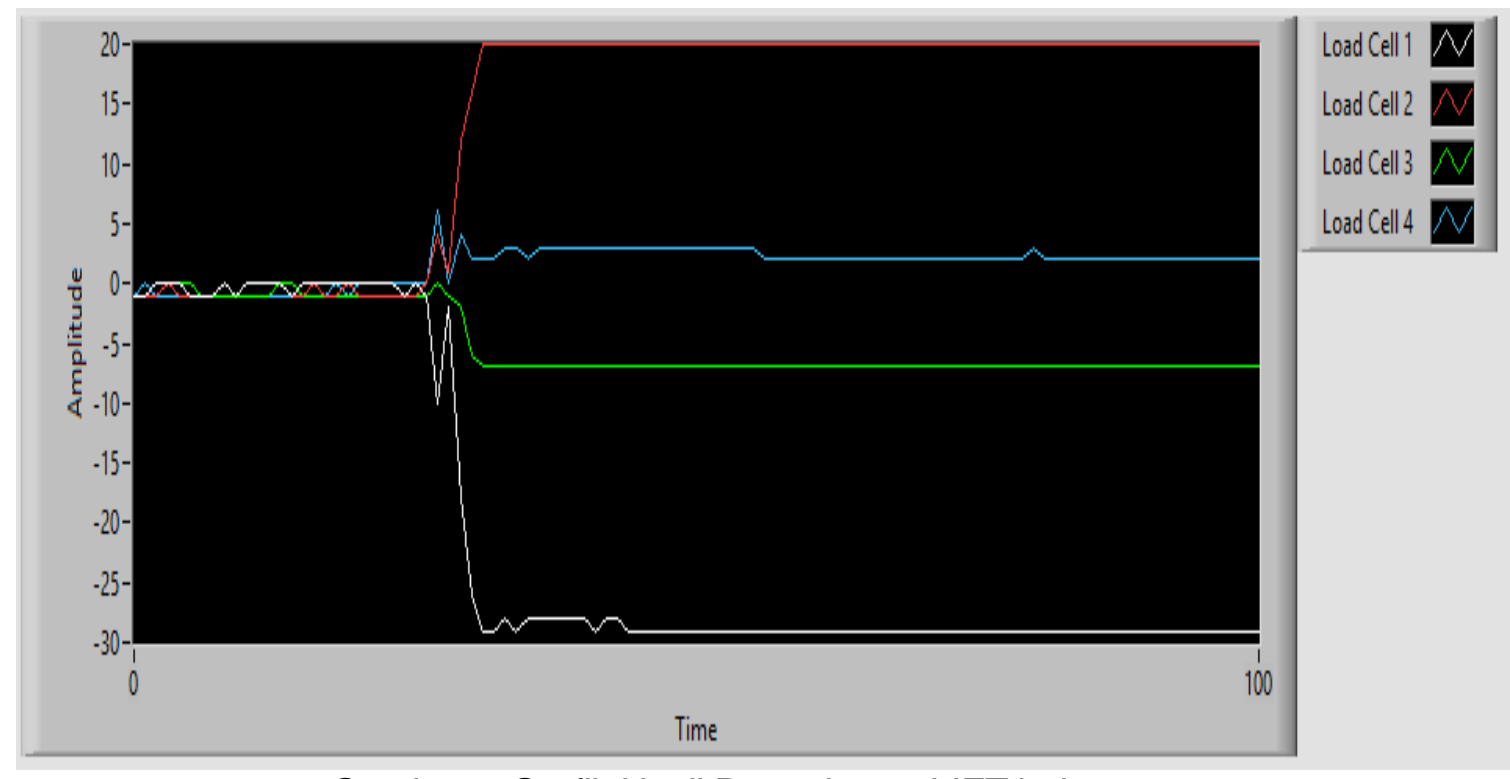

Gambar 6 Grafik Hasil Pengukuran LIFT beban 22g

Nilai LIFT didapatkan dari pembacaan Load cell 1 dan Load cell 2. Arah gaya mempengaruhi pembacaan nilai dari load cell. Jika arah gayanya kebawah, sensor satu akan bernilai negatif dan sensor dua bernilai positif sebaliknya jika arah gayanya keatas, sensor satu akan bernilai positif dan sensor dua akan bernilai negatif.

Awal pembacaan nilai yang terbaca mendekati 0 , hal ini terjadi karena beban belum digantungkan ke alat ukur. Pada detik 40 terjadi lonjakan dari masing-masing sensor, hal ini terjadi karena pada saat peletakan beban uji, bebannya masih bergerak sehingga mempengaruhi pembacaan load cell. Setelah beberapa saat pembacaan load cell mulai stabil. Nilai yang terbaca dari load cell 1 adalah $-29 \mathrm{~g}$. Pembacaan LIFT dari load celladalah $20 \mathrm{~g}$. Nilai yang terbaca mempunyai error sebesar $9 \mathrm{~g}$ untuk load cell 1 dan $2 \mathrm{~g}$ untuk load cell 2 .

Jurnal Sains dan Teknologi| 263 
Hasil menunjukkan bahwa load cell 3 dan load cell 4 juga mengalami perubahan nilai. Pada saat awal peletakan benda, kedua sensor ini juga mengalami lonjakan nilai yang akhirnya stabil. Perubahan nilai load cell 3 tidak terlalu signifikan, tetapi sensor 4 berubah dari $0 \mathrm{~g}$ menjadi $-7 \mathrm{~g}$. Perubahan ini disebabkan oleh beban yang diletakan pada saat pengukuran LIFT mempengaruhi load cell 4.
Pada saat pengukuran LIFT seharusnya nilai DRAG tidak terpengaruh karena arah gaya yang diberikan oleh beban berbeda dengan arah gaya yang dialami oleh load cell 3 dan load cell 4.

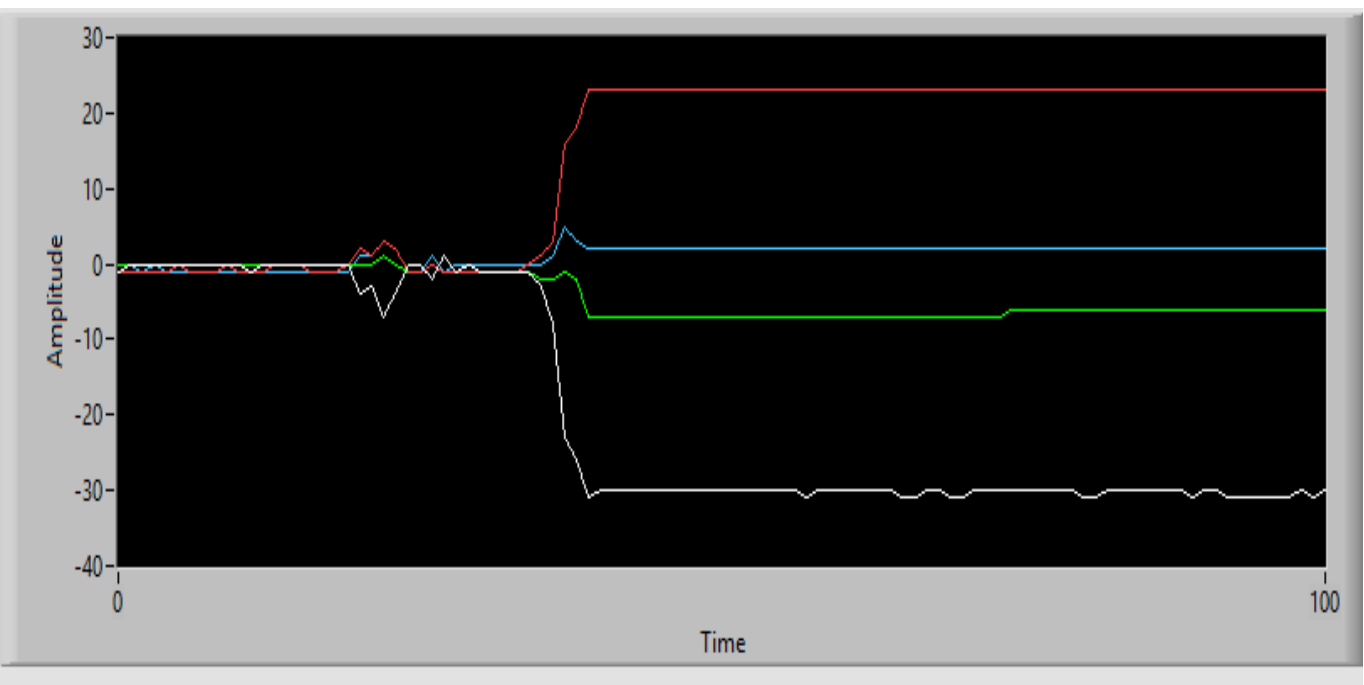

Gambar 7 Hasil Pengukuran LIFT Beban 25g

Gambar 7 menunjukkan grafik hasil percobaan pengukuran lift dengan beban $25 \mathrm{~g}$. Terjadi sedikit ripple pada tengahtengah pengukuran, ini disebabkan oleh adanya pergerakan yang dialami oleh sensor. Pada saat peletakan beban, sensor 1 dan 2 tidak mengalami ripple karena pada percobaan ini peletakan beban dilakukan dengan hati-hati. Grafik menunjukkan bahwa nilai yang terbaca oleh sensor 1 adalah adalah $-30 \mathrm{~g}$. Masih terdapat error sebesar $5 \mathrm{~g}$. Pembacaan sensor 2 sebesar $23 \mathrm{~g}$ dengan eror sebesar $2 \mathrm{~g}$. Sensor 3 dan sensor 4 mengalami lonjakan pada saat peletakan beban kemudian turun lagi dan stabil pada satu nilai.

Percobaan pengukuran LIFT dengan beban $34 \mathrm{~g}$ dan $88 \mathrm{~g}$ menunjukkan grafik yang hampir sama yaitu sensor 1 dan sensor 2 menunjukkan nilai yang hampir sama dengan nilai bebannya yaitu sebesar $43 \mathrm{~g}$ dan $31 \mathrm{~g}$ untuk beban $34 \mathrm{~g}$. Sensor 1 mempunyai error sebesar $9 \mathrm{~g}$ sedangkan sensor 2 mempunyai error sebesar $3 \mathrm{~g}$. Pengukuran LIFT dengan beban 88gmenunjukkan nilai sebesar $-94 \mathrm{~g}$ dengan error sebesar $6 \mathrm{~g}$ untuk sensor 1 . Sensor 2 menunjukkan nilai sebesar $90 \mathrm{~g}$ dengan error sebesar $2 \mathrm{~g}$. Sensor 3 dan sensor 4 tidak terlalu terpengaruh oleh pemberian beban pada alat ukur dengan arah gaya ke bawah.

Percobaan kelima adalah pengukuran DRAG yang dilakukan dengan cara berbeda dengan pengukuran LIFT. Pengukuran dilakukan dengan menggunakan benang seperti yang ditampilkan pada eksperimen setup dengan beban yang sama dengan pengukuran LIFT yaitu $22 \mathrm{~g}, 24 \mathrm{~g}$, $34 \mathrm{~g}$, dan $88 \mathrm{~g}$. Hasil pengukuran DRAG ditunjukkan oleh grafik pada gambar 8 . Pembacaan nilai gaya DRAG dengan beban $22 \mathrm{~g}$ sebesar $21 \mathrm{~g}$ untuk sensor 3 dengan error $1 \mathrm{~g}$. Sensor 4 menunjukkan hasil pembacaan sebesar $21 \mathrm{~g}$ juga dengan error 1g. Kedua sensor mempunyai nilai positif. Hal ini menunjukkan arah gaya dari kedua sensor ini searah untuk pengukuran gaya DRAG. Pada pengukuran DRAG tidak ada perbedaan 


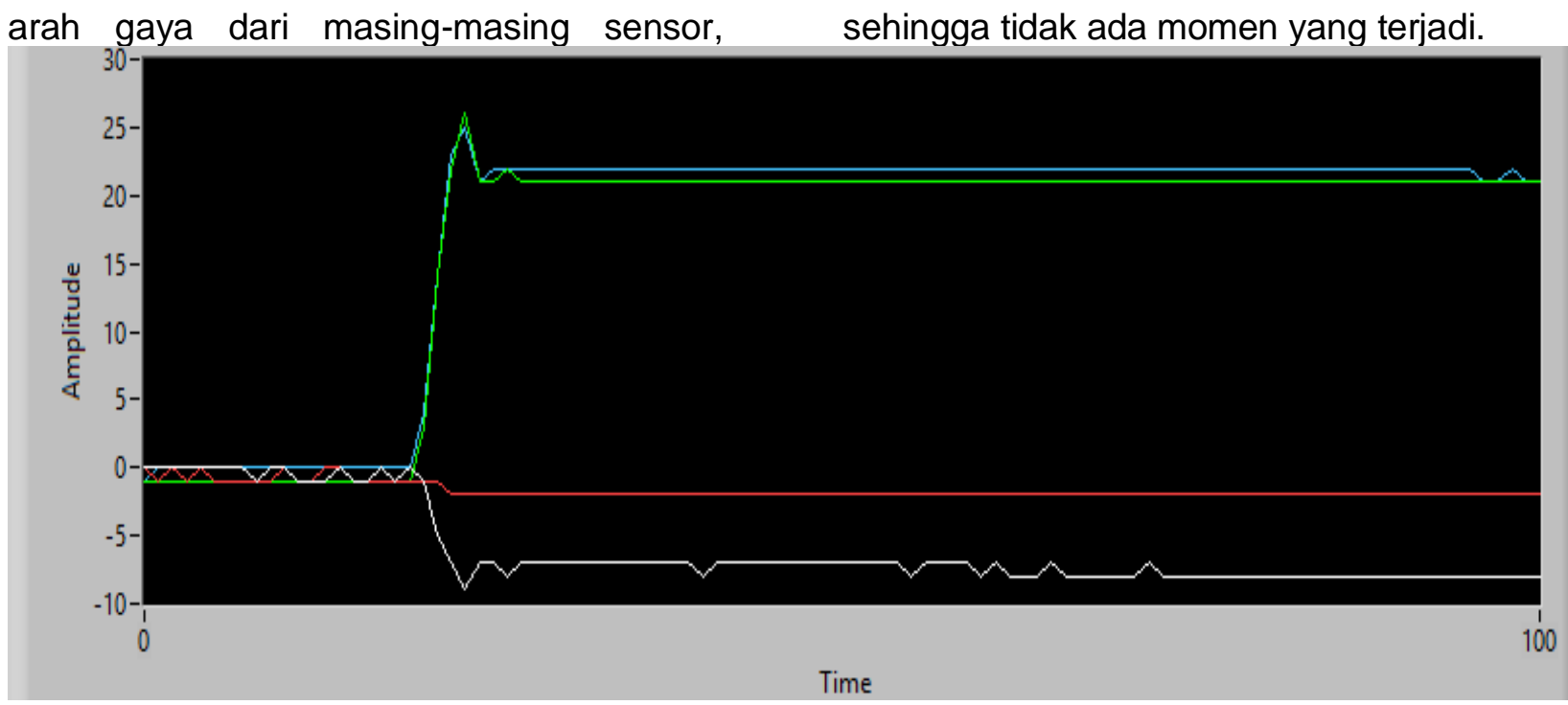

Gambar 8 Hasil Pengukuran Drag beban 22g

Grafik pada gambar 8 juga menunjukkan bahwa sensor 1 dan sensor 2 terpengaruh saat melakukan pengukuran DRAG. Perubahan nilai yang signifikan ditunjukkan oleh pembacaan sensor 1 yang mencapai $-9 g$. Perubahan nilai juga terjadi pada sensor 2 tetapi tidak terlalu signifikan. Hal ini disebabkan oleh pengaruh peletakan beban pada saat pengukuran DRAG. SPada saat melakukan pengukuran DRAG, nilai LIFT dapat diabaikan.

$$
\text { Percobaan keenam adalah }
$$

pengukuran DRAG dengan beban $25 \mathrm{~g}$. Hasil pengukuran ditunjukkan oleh grafik pada gambar 9. Pada percobaan ini, sensor 3 dan sensor 4 mengalami ripple pada saat beban diletakan tetapi kemudian nilai pembacaan stabil. Sensor 3 menunjukkan gaya DRAG yang terukur sebesar $24 \mathrm{~g}$ dengan error 1g. Sensor 4 menunjukkan nilai DRAG sebesar $23 g$ dengan error $2 g$. Hasil percobaan ini menunjukkan adanya selisih antara sensor 3 dan sensor 4 . Selisih ini bukan disebabkan oleh momen. Sensor
1 masih terpengaruh oleh pemberian beban untuk pengukuran DRAG. Hasil pengukuran menunjukkan nilai dari sensor 1 sebesar 9g. Sedangkan sensor 2 tidak terlalu terpengaruh oleh pengukuran DRAG. Hasil pengukuran menunjukkan sensor 2 membaca gaya yang terjadi sebesar $-2.5 \mathrm{~g}$. Pengukuran DRAG dengan menggunakan beban $34 \mathrm{~g}$, dibaca oleh sensor 3 sebesar $33 \mathrm{~g}$ dengan error $3 \mathrm{~g}$. Sensor 4 menunjukkan nilai sebesar 31 dengan error 2g. Sensor 1 masih terpengaruh oleh pengukuran DRAG. Sedangkan sensor 2 tidak terlalu terpengaruh. Percobaan terakhir adalah pengukuran DRAG dengan beban $88 \mathrm{~g}$. Dalam pengukuran ini sensor 3 membacaca $78 \mathrm{~g}$ yang berarti mempunyai error sebesar $10 \mathrm{~g}$. Sensor 4 menunjukkan nilai pembacaan sebesar $77 \mathrm{~g}$. 


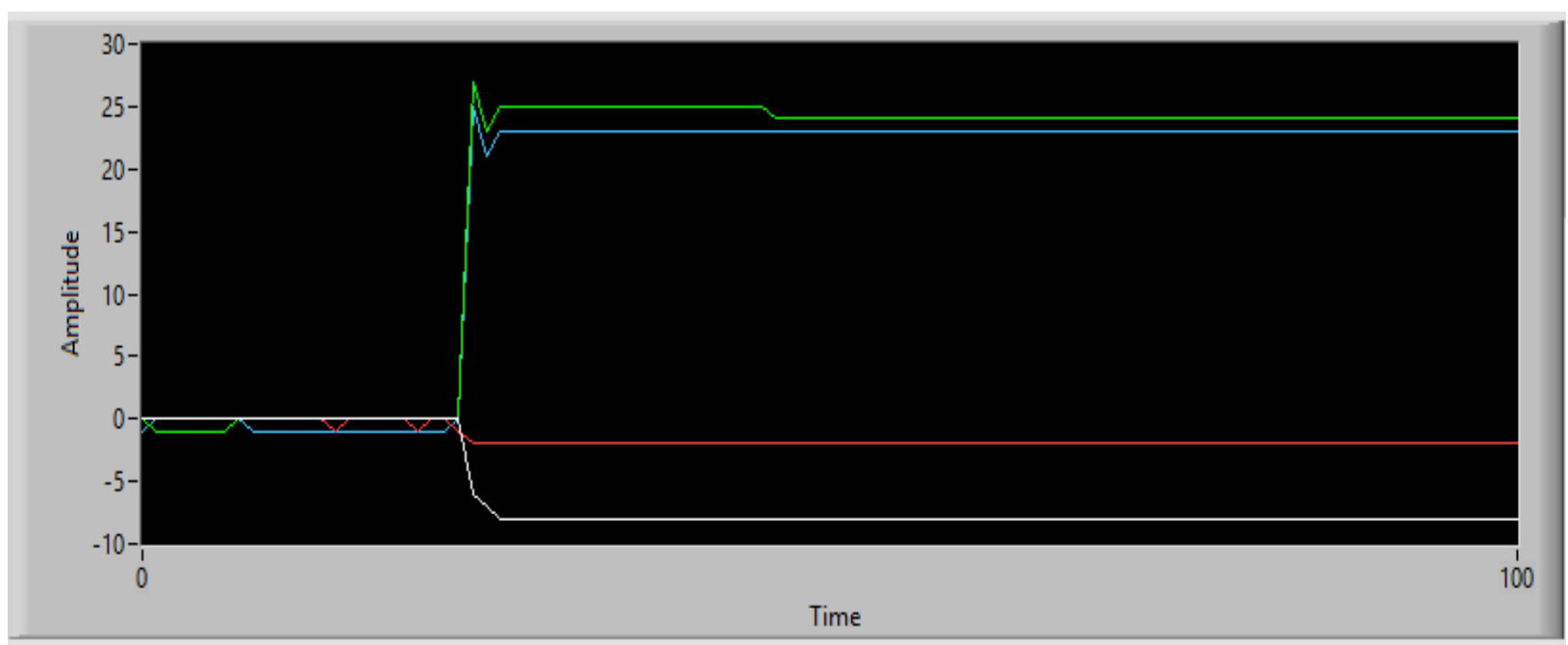

Gambar 9 Hasil Pengukuran Drag beban 25g

Hasil percobaan menunjukkan bahwa sistem pengukur gaya aerodinamika 3 derajat kebebasan telah bekerja dengan baik. Hal ini ditunjukkan oleh hasil pengukuran LIFT dan DRAG yang mempunyai error kecil dan mempunyai arah gaya yang seuai dengan teori. Selain dapat mengukur LIFT dan DRAG, alat ukur ini dapat menunjukkan gaya momen dari sebuah model pesawat atau model sayap. Momen dapat dihitung dengan menjumlahkan pengukuran lift 1 dan lift 2 . Jika nilai lift 1 dan lift 2 sama, maka tidak terjadi momen atau nilai momennya 0 . Nilai gaya momen ini juga penting dalam melakukan analisis perancangan pesawat terbang.

\section{SIMPULAN}

Kesimpulan dari makalah ini adalah aplikasi alat ukur tiga derajat kebebasan telah dapat bekerja dengan baik ditunjukkan oleh error yang kecil dan ketepatan arah gaya. Alat ini dapat diimplementasikan ke water tunnel untuk melakukan pengukuran gaya aerodinamika. Gaya aerodinamika yang dapat diukur dengan menggunakan aplikasi ini adalah LIFT, DRAG, dan MOMEN LIFT(ROLL).

\section{DAFT ARPUST AKA}

Beckner, C., \& E.Curry, R. (1985). Water Tunnel Flow Visualisation. Nasa Technical Memorandum, 86743, 16.
Doebelin, E. O. (2010). Measurement System : Application and Design. University of California: McGrawHill.

Erm, L. P. (2004). Dynamic Testing of Aircraft Models in a Water Tunnel. Paper presented at the 15th Australasian Fluid Mechanics Conference, The University of Sydney,Sidney,Australia.

Good, G. M. L., Howell, J. P., Passmore, M. A., \& Cogotti, A. (1998). A Comparison of On Road Aerodynamic Drag Measurements with Wind Tunnel Data from Pininfarina and MIRA. Paper presented at the International Congress and Exposition, Detroit, Michigan.

Husnayati, N., \& Moelyadi, M. A. (2013). Analisis Aerodinamika dan Studi Parameter Sayap CN-235 Kondisi Terbang Jelajah (Aerodynamic Analysis and Parametric Sturdy Of CN-235 Wing At Cruise Condition). Jurnal Teknologi Dirgantara, 10(2), 9.

Johnston, D. L. (1954). Load Cell Force Tranducers. Journal of The British Institution of Radio Engineers, 8.

Lubis, M. M. (2012). Analisis Aerodinamika Airfoil Naca 2412 Pada Sayap Pesawat Model Tipe Glider Dengan Menggunakan Software Berbasis Computional Fluid Dinamic Untuk Memperoleh Gaya Angkat Maksimum. E-Dinamis, II(2), 10. 
Ma, J., \& Song, A. (2013). Fast Estimation of Strains for Cross-Beams Six-Axis Force/Torque Sensors by Mechanical Modeling. Sensors, 13, 18. doi: 10.3390

Muller, I., Brito, R. M. d., Pereira, C. E., \& Brusamarello, V. (Cartographer). (2010). Load Cells In Force Sensing Analysis-Theory and a Novel Application.

Nan, L. (2013). The Methods of Drag Force Measurement in Wind Tunnels. (Master), University of Gavle.

Pifer, E. A., \& Bramesfeld, G. (2012). Measuring Wing Profile Drag using an Integrating Wake Rake. Technical Soaring, 36(3), 9.

Thrift, A. A., Brumbaugh, S. J., \& Thole, K. A. (2010). A Methodology to Measure Aerodynamic Forces on Cylinders in Channel Flow. Journal of Fluids Engineering, 132, 9.

Yuan, C., Luo, L.-P., Shin, K.-S., \& Han, C.S. (2013). Design and Analysis of a 6 DOF Force/Torque Sensor For Human Gait Analysis. Paper presented at the 13th International Conference on Control, Automation and System (ICCAS 2013), Kimdaejung Convention Center, Gwangju, Korea. 